\title{
Identifying Montana hunter/rancher problems and solutions
}

\author{
ERIK J. SWENSSON, AND JAMES E. KNIGHT
}

Authors are research technician, and extension wildlife specialist, Department of Animal and Range Sciences, Montana State University: Bozeman, Mont 59717 .

\begin{abstract}
A 1 year survey was developed to identify conflicts and solutions to conflicts between hunters and ranchers. A questionnaire was mailed to randomly selected groups of 1,000 hunters and 989 ranchers in Montana. One-third of the questionnaire was different for the 2 groups and consisted of questions relating to background information. The other two-thirds was identical between the groups and presented questions related to perceived problems and solutions, big game populations, importance of private and agricultural land to wildlife and hunter/rancher representation. Thirty-five percent of the hunters and $42 \%$ of the ranchers responded to the survey. The top 3 conflicts between hunters and ranchers as identified by hunters were too little access to private land, driving off roads, and trespassing. The top 3 solutions selected by hunters were greater consideration and appreciation by ranchers, better communication between groups, and better boundary identification. The top 3 problems identified by ranchers were driving off roads, trespassing, and too many hunters. The top 3 solutions selected by ranchers were stiffer penalties for violators, better communication between groups, and greater consideration and appreciation by hunters. Both hunters and ranchers ranked driving off roads and trespassing in their top 3 problems and ranked better communication and greater consideration and appreciation in their top 3 solutions. Hunters and ranchers have different $(P<0.01)$ views of who represents them in hunter/rancher related issues. Forty-seven percent of the hunters responding believe they represent themselves or have no representation; whereas, $57 \%$ of the ranchers responding indicated they are represented by livestock producer groups. Results of this survey indicate that hunters and ranchers have similar concerns and better communication will help alleviate conflicting interests.
\end{abstract}

Key Words: questionnaire, survey, problems, solutions, hunter conflicts, rancher conflicts.

Livestock production in Montana is a one billion dollar industry (Montana Agr. Stat. Serv. 1994). Hunting in Montana provides 333 million dollars of the 2.5 billion dollar tourism industry (Brooks 1988a, Brooks 1988b, Christensen et al. 1995). The land area of Montana is 37.6 million ha and over 24.3 million ha are agricultural lands. The state of Montana is comprised of $62 \%$ privately owned lands, $30 \%$ federal lands, $6 \%$ state lands, and $2 \%$

Manuscript accepted 7 Nov. 1997. tribal lands. Of the 24.3 million ha of agricultural lands, the average privately owned farm or ranch size is 1,000 ha (Montana Agr. Stat. Serv. 1994). Privately owned agricultural lands are important to Montana's economy and recreational opportunities.

Montana hunter/rancher relations have become increasingly strained over the past several years (Peterson 1992). Hunters are concerned about diminishing access to private and public land for hunting opportunities. Ranchers are concerned about increasing wildlife populations and feel their contributions to wildlife habitat are overlooked.

Conflicts between hunters and ranchers in Montana have been escalating in recent years. This is a trend occurring throughout the United States (Swan 1995, Peterson 1992). A survey conducted in New Mexico by Knight et al. (1987) found that one obstacle between better hunter/rancher relationships was negative attitudes that a small number of hunters and ranchers had towards each other. Peterson (1992) reported problem solving between hunters and ranchers had become more confrontational and oriented towards single issues.

In order to address hunter/rancher conflicts and solutions, it is first necessary to identify perceived problems and possible solutions. Three different methods to collect information have been utilized and all have inherent shortcomings. Advocacy group membership surveys are often used to identify problems because members are available and readily give their views. Unfortunately, little effort has been made to determine if they reflect the views of the population as a whole or just the views of an active segment (Sudman and Presser 1981). Public hearings and meetings is another method of identifying problems. Johnson et al. (1993) found that meeting attendees stated more extreme views than the general population. The use of questionnaires has been an effective way of getting input representative of an entire population, but because surveys have been aimed at a single group they have not been useful in identifying commonalities between groups (Knight et al. 1987).

The objective of this study was to identify perceived problems and possible solutions between hunters and ranchers in Montana.

\section{Materials and Methods}

A questionnaire designed to identify perceived problems and possible solutions to hunter/rancher conflicts was mailed to 1,000 Montana resident big game hunters and 989 Montana ranchers. Identification of stakeholders in the hunter/rancher issues was determined to develop appropriate mailing lists. The stakeholders 
for hunters were determined to be avid resident Montana sportsman. The stakeholders for ranchers were determined to be people depending upon agriculture for their livelihood. Hunters were randomly selected from the Montana Fish, Wildlife, and Parks database of deer (Odocoileus spp. Rafinesque and Zimmermann), elk (Cervus elaphus Nelsoni [L.]) and antelope (Antilocapra americana [Ord.]) 1994 hunting permit purchasers. One thousand hunters purchasing a resident combination license for deer and elk and who drew an antelope special permit were selected from the database. Rancher names were randomly selected from lists obtained from county extension agents. County extension agents in Montana were sent letters requesting the names of 25 ranchers, who controlled a minimum of $404 \mathrm{ha}$, and who in the opinion of the county agent, had views on hunter/rancher related issues representative of the county.

The survey consisted of a cover letter, the questionnaire, and a map outlining designated hunting regions within the state. The cover letter explained how names for the mailing lists were obtained, who was sponsoring the project, and the purpose for conducting the survey. The Montana Fish, Wildlife and Parks regional map was included on the back of each letter for questions pertaining to regional data.

A portion of the survey consisted of questions that were specific to each of the 2 groups (past hunting experience, years hunted, locations of ranch, present hunting allowed, etc.). These questions were designed to determine background characteristics of hunters and ranchers. Questions related to perceived conflicts and possible solutions, perceived trends in game populations, importance of agriculture and private lands contribution to wildlife, and representation were asked in identical format of both hunters and ranchers. Survey questions were written in a closed response format, limiting the number of possible responses. A follow-up telephone survey was conducted after the return of the mail survey to obtain information from non-respondents. Possible non-respondent bias was addressed using twenty-five people, randomly selected from both the hunter list and the rancher list, who did not respond to the mail survey.

Problems and solutions were analyzed individually and compared between groups. The survey responses 1 through 6 were grouped to strengthen the low and high responses. The problems were grouped as 1 and 2 being no problem, 3 and 4 as a problem and 5 and 6 as a major problem. The solutions were grouped as 1 and 2 having little possibility as a solution, 3 and 4 as potential solutions and 5 and 6 as high potential solutions. Problems and solutions comparisons between hunters and ranchers were analyzed using the t-tests procedure of SAS (1992). Analysis of variance was used to evaluate hunter/rancher conflicts and solutions by region using the GLM procedure of SAS (1992). Hunter, rancher, region, and all two-way interactions were fitted as main effects in the model.

\section{Results}

Thirty-five percent of the hunters and $42 \%$ of the ranchers responded to the mail survey. Sixty-five percent of the hunters responding to the survey had more than 10 years of hunting experience, which fits the description of the defined group of hunting stakeholders. Sixty percent of the ranchers responding to the survey owned or managed property from 404 to 4,084 ha, matching the rancher stakeholder description.
Table 1. Ranking of conflicts (1-14) that hunters $(N-349)$ and ranchers $(N=395)$ classify as a major problem.

\begin{tabular}{lcc}
\hline Conflict & Hunter Rank & Rancher Rank \\
\hline Damage to property by hunters & $8^{\mathrm{a}}$ & $4^{\mathrm{b}}$ \\
Lituer from hunting & 6 & 6 \\
Too many hunters & 5 & 3 \\
Damage to roads & 13 & 8 \\
Driving off roads & $2^{\mathrm{a}}$ & $1^{\mathrm{b}}$ \\
Too little access & $1^{\mathrm{a}}$ & $12^{\mathrm{b}}$ \\
Lack of proper maps & $7^{\mathrm{a}}$ & $9^{\mathrm{b}}$ \\
Damage to livestock & $14^{\mathrm{a}}$ & $10^{\mathrm{b}}$ \\
Unclear property postings & $4^{\mathrm{a}}$ & $11^{\mathrm{b}}$ \\
Trespassing & $3^{\mathrm{a}}$ & $2^{\mathrm{b}}$ \\
Negative public statements by hunters & 11 & 5 \\
Negative public statements by ranchers & $9^{\mathrm{a}}$ & $13^{\mathrm{b}}$ \\
Abuse of land by hunters & 10 & 7 \\
Abuse of land by ranchers & $12^{\mathrm{a}}$ & $14^{\mathrm{b}}$ \\
\hline
\end{tabular}

values within the same row with different superscripts differ $(P<0.01)$.

Hunters and ranchers were asked to identify perceived conflicts between the 2 groups and were given 14 choices. The respondents were asked to rank each conflict from 1 to 6 , with 1 meaning it is not a problem and 6 meaning it is a major problem. Conflicts that scored as a major problem were ranked for both hunters and ranchers (Table 1). The top 3 conflicts ranked as a major problem by hunters were too little access to private land, driving off roads, and trespassing (Figure 1,2, and 3). The top 3 conflicts ranked by ranchers as a major problem were driving off roads, trespassing and too many hunters (Figure 2, 3, and 4). Although these items were ranked by both hunters and ranchers as the top 3 major problems there were some differences between the 2 groups. Ranchers ranked driving off roads and trespassing as greater $(P<0.01)$ problems than hunters. Too little access to private land was ranked as more $(P<0.01)$ of a problem by

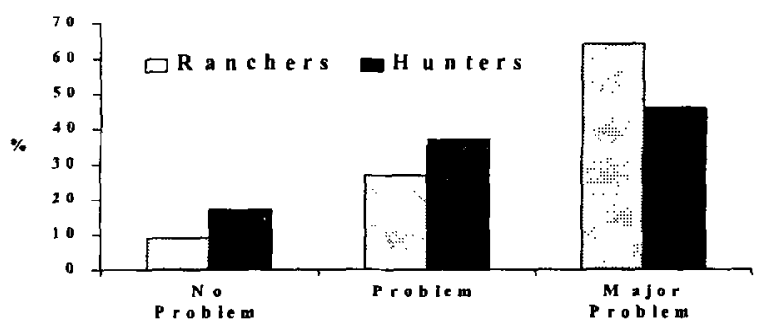

Fig. 1. Hunter/rancher response when asked if driving off roads was a problem.

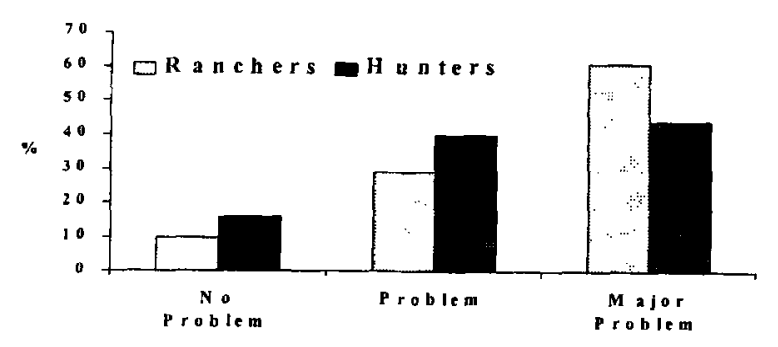

Fig. 2. Hunter/rancher response when asked if trespassing was a problem. 


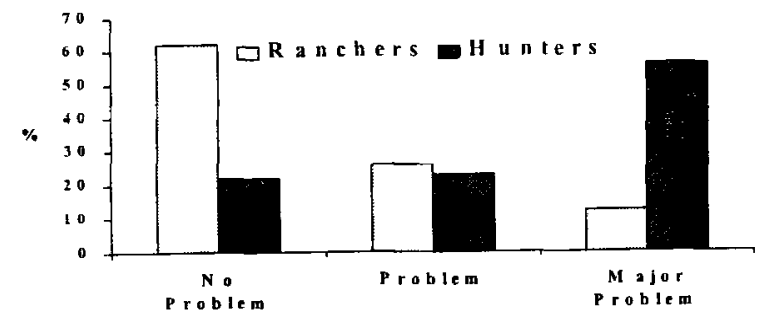

Fig. 3. Hunter/rancher response when asked if too little access was a problem.

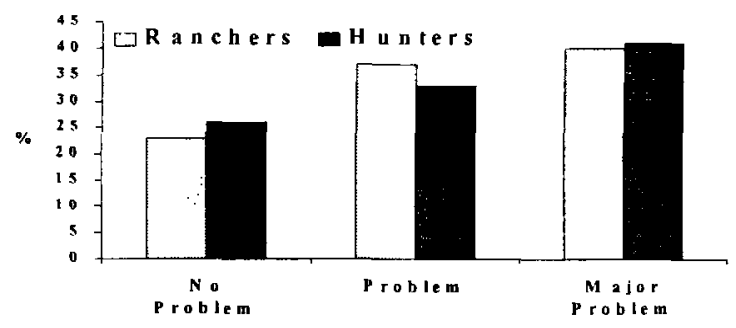

Fig. 4. Hunter/rancher response when asked if too many hunters was a problem.

hunters than ranchers. Too many hunters was ranked as a major problem by both hunters and ranchers.

Identifying perceived conflicts which hunters and ranchers rated as no problem is as important as conflicts which are identified as major problems. Three choices that hunters perceived as no problem include damage to livestock, abuse of land by ranchers, and damage to roads. Ranchers identified choices that they perceived as no problem as abuse of land by ranchers, too little access, and unclear property postings. Hunters and ranchers both agreed that abuse of land by ranchers is not a problem but ranchers ranked it lower $(P<0.01)$ than hunters. Too little access was considered a major problem by hunters but not a problem by ranchers $(P<0.01)$. Other choices, which were ranked as no problem and were different $(P<0.01)$ between hunters and ranchers include lack of proper maps and negative public statements by ranchers.

Ten choices for possible solutions to conflicts were asked of both hunters and ranchers. The respondents were asked to rank each possible solution from 1 to 6 , with 1 having low potential as a solution and 6 having high potential as a solution. Solutions having a high potential were ranked for both hunters and ranchers (Table 2). Hunters ranked greater consideration and appreciation by ranchers, better communication between hunters and ranchers, and better boundary identification as having the highest potential as solutions (Figure 5, 6, and 7) to hunter/rancher conflicts. The top 3 solutions to hunter/rancher conflicts as identified by ranchers were stiffer penalties for violators, better communication between hunters and ranchers, and greater consideration and appreciation by hunters (Figure 6,7, and 8).

Hunters ranked greater consideration and appreciation by ranchers as having higher $(P<0.01)$, potential for a solution than ranchers. Stiffer penalties for violators was ranked as having higher $(P<0.01)$ potential as a solution by ranchers than by
Table 2. Ranking of solutions $(1-10)$ that hunters $(N=349)$ and ranchers $(\mathrm{N}=395)$ classified as having high potential.

\begin{tabular}{lcc}
\hline Conflict & Hunter Rank & Rancher Rank \\
\hline Retter communication between the 2 groups & 3 & 2 \\
Stiffer penalties for violators & $5^{\mathrm{a}}$ & $1^{\mathrm{b}}$ \\
More involvement by state and federal agencies & 9 & $9^{\mathrm{b}}$ \\
Less involvement by state and federal agencies & 6 & 5 \\
Shorter hunting seasons & $10^{\mathrm{a}}$ & $6^{\mathrm{b}}$ \\
Longer hunting seasons & $7^{\mathrm{a}}$ & $10^{\mathrm{b}}$ \\
Better boundary identification of public land & $4^{\mathrm{a}}$ & $7^{\mathrm{b}}$ \\
private lands & 8 & 8 \\
More game wardens & $1^{\mathrm{a}}$ & $4^{\mathrm{b}}$ \\
Greater consideration for the concerns of the & & \\
other group & $2^{\mathrm{a}}$ & $3^{\mathrm{b}}$ \\
Greater appreciation for the contributions of the & \\
other group & \\
ab values within the same row with different superscripts differ $(\mathrm{P}<0.01)$.
\end{tabular}

hunters. Hunters and ranchers agreed that better communication between the 2 groups has high potential as a possible solution to hunter/rancher conflicts.

It is important to identify possible solutions that hunters and ranchers feel have no potential to resolve conflicts. Choices that hunters rank as having no potential as a solution include shorter hunting seasons, longer hunting seasons, and more involvement by state and federal agencies. Choices that ranchers feel have no potential as possible solution to conflicts are shorter hunting seasons, longer hunting seasons, and more involvement by state and federal agencies. More game wardens and less involvement by state and federal agencies were ranked by hunters and ranchers as having low potential as a possible solution.

Hunters and ranchers were asked a series of questions relating to trends in big game populations, hunting pressure, and access (Table 3). The survey also contained questions pertaining to the importance of private lands and agriculture to wildlife and their

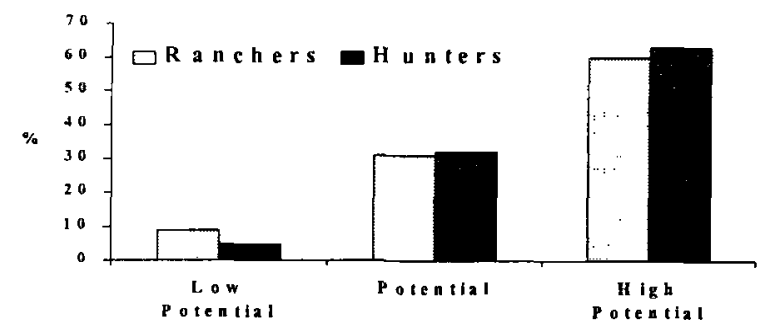

Fig. 5. Hunter/rancher response to the potential of greater consideration and appreciation for the other group as a solution to hunter/rancher conflicts.

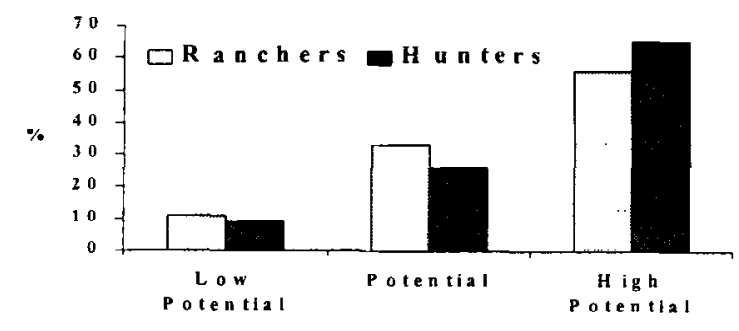

Fig. 6. Hunter/rancher response to the potential of better communication between groups as a solution to hunter/rancher conflicts. 


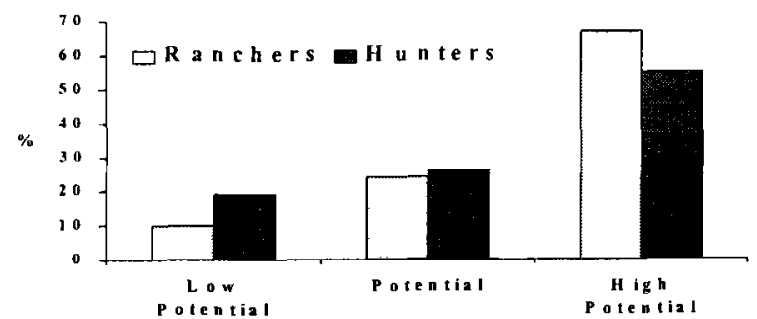

Fig. 7. Hunter/rancher response to the potential of better boundary identification as a solution to hunter/rancher conflicts.

habitats. Hunters and ranchers responding to the survey believe deer and elk populations have increased in the last 5 years in Montana. Fifty-six percent of the hunters and $68 \%$ of the ranchers feel deer populations have increased, while $50 \%$ of the hunters and $68 \%$ of the ranchers believe that elk populations have increased. Pronghorn antelope populations were viewed differently $(P<0.01)$ by hunters and ranchers. Hunters opinions on pronghorn antelope populations were split, with $30 \%$ of the hunters responding that antelope populations have increased, and $30 \%$ of the hunters responded that antelope have decreased. Forty-three percent of the ranchers feel antelope populations have increased in the last 5 years.

Hunters and ranchers responses were similar when asked about hunting pressure and access to private lands. Eighty-four percent of the hunters and $69 \%$ of the ranchers stated that hunting pressure has increased in Montana in the last 5 years. In contrast to this, $78 \%$ of the hunters and $66 \%$ of the ranchers stated that access to private lands in Montana has decreased in the last 5 years.

Hunters and ranchers were asked to rate the effect private lands and agriculture have on wildlife habitat. Their choices were very positive, positive, no effect, negative and very negative. Seventy three percent of the hunters and $92 \%$ of the ranchers rated private lands and agriculture as having a positive or very positive effect on wildlife and their habitat.

The last question on the survey asked hunters and ranchers who they felt represented them on hunter/rancher related issues. Fortyseven percent of the hunters responding to the survey stated they represent themselves or have no representation in hunter/rancher related issues. Ranchers responded that $57 \%$ were represented by a producer group of some kind in these issues.

The non-respondent survey was not different $(P>0.8)$ between hunters and ranchers who responded to the written survey and those telephoned during the non-respondent survey. Non-respondent data were not combined with the mail response data. Telephone data were only used to test for differences between respondents and non-respondents of the mail survey.

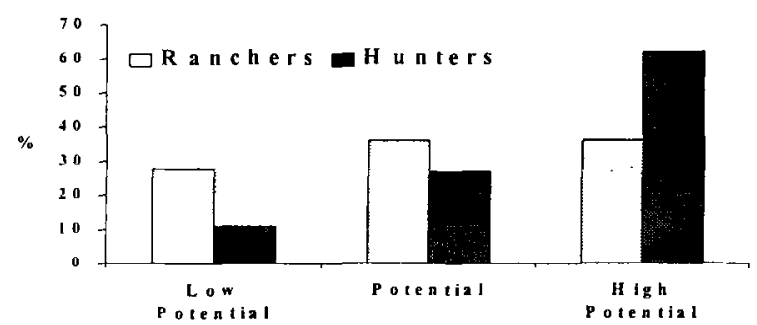

Fig. 8. Hunter/rancher response to the potential of stiffer penalties for violators as a solution to hunter/rancher conflicts.

\section{Discussion}

Hunters and ranchers indicating there were conflicts between the groups ranked driving off roads and trespassing as major problems. In a survey of wildlife administrators throughout the United States, Wright and Kaiser (1986) found that trespassing and property damage were major problems landowners faced. It is important to identify issues that both groups feel are no problem, especially when looking to identify common ground issues between the groups. Issues that could be important for wildlife managers focus are those that hunters and ranchers feel very differently about. This survey found these issues to include damage to property by hunters, damage to roads, too little access, unclear property postings, and negative public statements. Many of these areas of conflict can be resolved through improved communication between the groups.

The identification of conflicts may be important, but often hunter and rancher opinions to solutions to conflicts are disregarded. It is important to realize that people involved in conflicts have possibly thought of ways to resolve the problem. Literature rarely focuses on positive aspects of hunter/rancher relations. Elliot (1992) proposed that hunters and landowners can work out conflicts through better communication and education. Knight et al. (1987) reported that most hunters and ranchers had a sincere desire to improve relationships.

Responding hunters and ranchers ranked better communication between groups and greater consideration and appreciation of the other group as 2 of their top 3 solutions. Both of these potential solutions require more communication and education for both groups. Solutions which hunters and ranchers recognized as having little potential to resolve conflicts include shorter hunting seasons, longer hunting seasons, and more involvement by state and federal agencies. Both hunters and ranchers indicated that changes in present management of hunting seasons is not a positive solution to resolving conflicts.

Table 3. Percentage of hunter $(N=349)$ responses to big game populations, hunting, pressure, and access.

\begin{tabular}{|c|c|c|c|c|c|c|}
\hline \multirow[t]{2}{*}{ Items } & \multicolumn{3}{|c|}{ Hunter } & \multicolumn{3}{|c|}{ Rancher } \\
\hline & Increased & Decreased & Same & Increased & Decreased & $\overline{\text { Same }}$ \\
\hline & - - - - - & $\cdots$ & $-\cdots$ & $\ldots \ldots$ & $\ldots \ldots$ & -- \\
\hline Deer & 55 & 13 & 25 & 66 & 11 & 18 \\
\hline Elk $^{b}$ & 49 & 11 & 20 & 57 & 3 & 5 \\
\hline Antelope & 35 & 30 & 23 & 39 & 13 & 21 \\
\hline Hunting pressure & 82 & 0 & 11 & 66 & 3 & 22 \\
\hline Access to private lands ${ }^{b}$ & 6 & 77 & 9 & 7 & 65 & 15 \\
\hline
\end{tabular}

apercentages do not add up to 100 because "don't know" response is not included.

indicates differences of $P<0.01$ between hunters and ranchers. 
Hunters and ranchers both agree that hunting pressure has increased in the last 5 years. The popularity of hunting continues to grow, especially in the western United States. As hunting pressure increases, there is an increased demand for access by hunters. Both hunters and ranchers report that access to private land for hunting has decreased in the last 5 years. Cook and Cable (1992) claimed that decreases nationwide in the public's participation in hunting could be blamed on decreased access to land.

Private land provides important habitat for wildlife species throughout Montana. Hunters and ranchers agree that private land has a positive effect on wildlife in Montana. Most large blocks of private land that provide habitat for big game are also under some kind of agricultural management. Both hunters and ranchers responded that agriculture in Montana has a positive effect on wildlife. It is important to recognize that both groups appreciate private property and agriculture and its effects on wildlife and wildlife habitat. This identifies an important common ground issue between the 2 groups.

In order to promote positive ideas and educate hunters and ranchers, ideas must be widely and clearly disseminated to the public. Forty-seven percent of the hunters responding to the survey believe they represent themselves or have no representation on hunter/rancher related issues. In contrast to this, $57 \%$ of the ranchers believe they are represented by a producer group (i.e., Montana Stockgrowers, Farm Bureau or Montana Wool Growers) on hunter/rancher related issues. This gives ranchers an advantage on bcing more educated on issues and events which could affect both groups. Beucler et al. (1994) found a major concern of Idaho hunter groups was organization and public relations. Hunter groups need to build stronger ties with both the hunting and ranching communities if conflicts are going to be alleviated in the future.

This study points out some important information about Montana hunters and ranchers. Results indicate that hunter and rancher opinions in areas of possible conflict and solution are similar. This information could be used to establish common ground issues between the groups and help promote the idea of hunters and ranchers working together on wildlife issues. One key point of this study is the issue of representation. Better representation by both groups is a vital link to establishing better communication between Montana hunters and ranchers.

\section{Literature Cited}

Brooks, R. 1988a. The net economic value of deer hunting in Mont. Montana Dept. Fish, Wildlife and Parks. Helena, Mont.

Brooks, R. 1988b. The net economic value of elk hunting in Montana. Mont. Dept. Fish, Wildlife and Parks. Helena, Mont.

Beucler, M., D.E. Toweill, T. McArthur, and C.L. Groen. 1994. Newcomers to Idaho: perception, reality and management implications. pp. 12-24. In: Rosier, C. (ed.), Proc.: 74th Ann. Conf., Western Assoc. of Fish and Wildl. Agencies, Anchorage, Alaska.

Christensen, N.A., N.L. Menneng, and N. Moisey. 1995. Non-resident travel to Montana: 1991-1994. Inst. Tourism and Recr. Res. Res. Note 21. Helena, Mont.

Cook, P.S. and T.T. Cable. 1992. Developing policy for public access to private land: a case study, pp. 76-93. In: Mangum, W.R. (ed.) American Fish and Wildlife Policy: The Human Dimension. So. Illinois University Press, Carbondale and Edwardsville, Ill.

Elliott, D.S. 1992. Hunters, we have a problem: the state of contemporary hunter ethics and hunter education, pp. 116-123. In: Burke, S.F., M. LaBarbera, and D. Grann, (ed.), Proc.: Governor's Symposium on North America's Hunting Heritage. Bozeman, Mont.

Johnson, K.N., R.L. Johnson, D.K. Edwards, and C.A. Wheaton. 1993. Public participation in wildlife management: opinions from public meetings and random surveys. Wildl. Soc. Bull. 21:218-225.

Knight, J.E., L. Foster, and V.D. Lansford. 1987. Hunter-rancher relationships in New Mexico. Rangelands 9(4):149-151.

Montana Agricultural Statistics Service. 1994. Montana Agricultural Statistics, Vol. XXXI, Helena, Mont.

Peterson, J. 1992. A landowners' view of hunters, pp. 124-129. In: Burke, S.F., M. LaBarbera, and D. Grann, (ed.), Proc.: Governor's Symposium on North America's Hunting Heritage., Bozeman, Mont.

SAS. 1992. SAS User's Guide: Statistics. SAS Inst., Inc., Cary, N.C.

Sudman, H. and S. Presser. 1981. Response effects in surveys, A review and synthesis. Aldine Publishing Company. Chicago, Ill.

Swan, J.A. 1995. In Defense of Hunting. Harper Collins Publishers. New York, N.Y.

Wright, B.A. and R.A. Kaiser. 1986. Wildlife administrators' perceptions of hunter access problems: a national overview. Wildl. Soc. Bull. 14:30-35. 